\title{
John Ross (1777-1856)
}

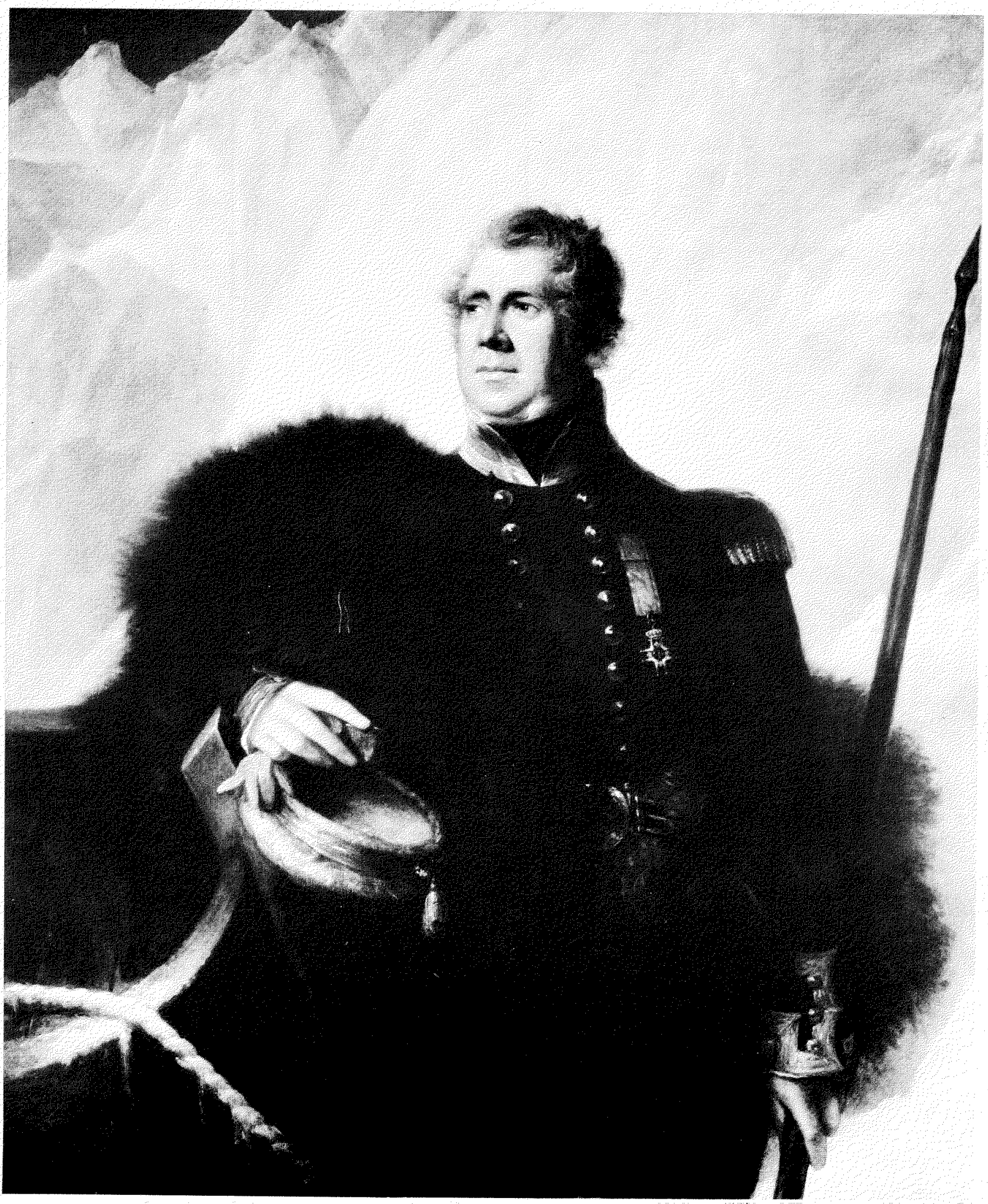

Portrait of Sir John Ross by J. Green, 1833. National Portrait Gallery, London (no. 314). 
The space accorded John Ross in the history of the Canadian Arctic is out of proportion to his achievement, circumstances arising from his invincible self-confidence and refusal to admit error. When convicted of blunders - obvious but excusable he retorted on his critics with a repetitive bitterness that added much to his celebrity, although it did little for his reputation. His first unlucky arctic voyage at least restored the faded character of William Baffin; his second was a miracle of survival. In retrospect, its drama was a little dulled by Ross's tedious and wordy narrative, but it exemplified his leadership and undaunted courage. Ross's combativeness probably helped his popularity, and his futile voyage, at the age of 73 , to the rescue of John Franklin won him admiration and respect.

John Ross, the younger son of a good Scottish family, joined the Navy and served in the Revolutionary and Napoleonic wars. After the wars, he was appointed to re-survey Baffin Bay and seek an outlet from that basin to the Pacific. He rounded the bay in 1818 , confirmed Baffin's nearly-forgotten survey, but erroneously declared that the three possible western outlets were blocked by land. Parry and others of his officers disagreed with his opinion. In 1819-20 Parry proved Lancaster Sound an open channel leading into the heart of the Canadian archipelago, but he failed to prove the existence of an outlet to the Pacific - a Northwest Passage. Nonetheless John Barrow, Secretary to the Admiralty, bitterly censured Ross for his mistake, to which Ross replied angrily.

Ross, though poorly educated, was courageous, enterprising, and inventive. Refused fresh naval employment, he secured the backing of Felix Booth, a wealthy distiller, for the discovery of the passage. His plan was to take a small ship of light draft, equipped with auxiliary steam power, to the bottom of Regent's Inlet, and make his way west along the continental shore.

He set out in 1829 in the little Victory with his nephew James Ross as second-in-command. The ship was fitted with paddlewheels that could be hoisted up to avoid contact with ice, but the experiment was not a success. With great difficulty, Ross penetrated to Lord Mayor's Bay at the bottom of the inlet, where he dismantled his worthless engine and flung it on the beach. The ship was soon frozen in and, after three winters, was finally abandoned by her crew. Such long confinement might have wiped out the entire crew by scurvy, but Ross won the friendship of the local Eskimos, who supplied him with enough fresh meat to keep his men in good health. The natives also taught him to use sledges, and although the 52-year-old John Ross was too old for strenuous sledging, his nephew James conducted most of the expedition's geographical work through this newly-learned method of travel.

After three winters the Victory was deserted, and the crew, hauling sledges, travelled up the east shores of Boothia Peninsula and Somerset Island to Lancaster Sound, with the hope of being rescued by whalers. In this they were disappointed and went many miles back to Fury Beach on Somerset Island, where Parry had cached the supplies of his wrecked ship, the Fury. In the summer of 1833 they returned to Lancaster Sound, where they were at last picked up by a whaler and carried back to a country that had long given them up for dead.
Ross's dogmatic self-assertiveness had procured him malicious critics, but the country at large could not withhold its admiration for his daring endeavour and his maintenance of the discipline and courage of his crew through four seasons of unforeseen hardship and danger, and, towards the last, of frightful suspense. The Admiralty discharged his indebtedness to his crew, whose period of employment had vastly exceeded the terms of their contract. As well, a Committee of the House of Commons, brushing aside hostile criticism, expressed approval of his expedition and awarded him a grant of $£ 5000$ for having so well sustained the national honour. King William IV, ex-officer and ever the sailor's friend, granted him a knighthood. After-serving as British consul in Sweden, Ross retired with the rank of rear-admiral.

He still felt a lively interest in the Arctic and, in 1847, was the first to raise the alarm over the prolonged absence in the North of the last Franklin expedition. When the first rescue expeditions failed, the old sea dog, although over 70 years of age, obtained help from private sources and took his own ship into Barrow Strait on an equally fruitless search. He died in 1856.

Ross was of an original - but in his youth apparently uncultivated - mind. Self-educated and unused to the give-andtake of academic life, he was positive and overbearing, although no more than his chief critic, John Barrow. He was an early advocate of the introduction of steam power, and this antagonized the conservative Navy chiefs. Although bitter in controversy, he was amiable in social intercourse. The American explorer Elisha Kent Kane, who met him in Barrow Strait in 1850, was charmed with his cordiality; in the same season Lt. Sherard Osborn made a winter journey of some distance to pay a courtesy visit to the old sailor, his senior by 50 years. Ross's contribution to arctic endeavour was considerable, and his eccentricities helped to keep up public interest in the North.

\section{FURTHER READINGS}

KANE, ELISHA KENT. 1854. The U.S. Grinnell Expedition in Search of Sir John Franklin: A Personal Narrative. London: Sampson Low, Son, and Co.

NEATBY, L.H. 1970. Search for Franklin. Edmonton: M.G. Hurtig Ltd. PARRY, ANN. 1963. Parry of the Arctic. London: Chatto and Windus. ROSS, JOHN. 1819. A Voyage of Discovery. London: John Murray. 1835. Narrative of a Second Voyage in Search of a North-west Passage. London: A.W. Webster.

L.H. Neatby

1610 - 1223 Temperance Street

Saskatoon, Saskatchewan, Canada

S7N 0P2 